DOI 10.37882/2223-2982.2020.07.16

\title{
РЕПРЕЗЕНТАЦИЯ КОНЦЕПТА «БОРЬБА» В ВЫСКАЗЬВАНИЯХ И АФОРИЗМАХ ЯКУТСКИХ ПИСАТЕЛЕЙ
}

\section{REPRESENTATION OF THE CONCEPT "FIGHT" IN THE STATEMENTS AND ACHORISMS OF YAKUT WRITERS \\ E. Kudrin \\ I. Pavlova}

Summary: The article discusses the understanding of the concept of «struggle» by the people of Sakha. An attempt was made to an interdisciplinary analysis of one of the universal concepts: at present, the concept of "wrestling" in the sports field from the point of linguoculturology has not been sufficiently studied. The content of the concept is revealed on the basis of the analysis of the statements of Yakut writers, scientists, public figures.

Keywords: concept, struggle, people of Sakha, national struggle, nomination, term.

\author{
Кудрин Егор Петрович \\ К.п.н., дочент, Северо-Восточный федеральный \\ университет им. М.К. Аммосова \\ kudrinep@mail.ru \\ Павлова Ирина Петровна \\ К.филол.н., дочент, Северо-Восточный федеральный \\ университет им. М.К. Аммосова \\ ipavlova27@mail.ru
}

Аннотация: В статье рассматривается понимание концепта «борьба» народом Саха. Предпринята попытка междисциплинарного анализа одного из универсальных концептов: в настоящее время концепт «борьба» в спортивной области с точки лингвокультурологии недостаточно изучен. Содержание концепта раскрывается на основе анализа высказываний якутских писателей, ученых, общественных деятелей.

Ключевые слова: концепт, борьба, народ Саха, национальная борьба, номинация, термин.

Тустаччы по знач. основы; борец, тусту, тустук,

Тусун, тустабыт - бороться, барахтаться, сражаться, драться. (бо5ону кытта туста), прибыл я с сильным бороться [СЯЯ Э.К. Пекарского, 1958: 2863].

ж. 1. (стычка) хапсыһыы, киирсии; воздушная схватка салгынна хапсыһыы;

2. схватки мн. талыы; родовые схватки төрүүр талыы, о丂олонор талыы.

Бой сущ. кыргыһыы, охсуһyу, сэриилэһии,

Бой ж. 1. (сражение) кыргыһыы, сэриилэһии, oxсyhyу; воздушный бой салгынна кыргыһыы; классовые бой кылаастар охсуһуулара;

2. спорт, күрэхтэһии, күрэс;

3. (часов, барабана) охсуу, тыас;

4. (ружья) тэбии;

5. (разбивание) үлтүрүтүү, алдьатыы;

6. собир. (битое стекло) үлтүркэй, бытархай; \# взять с бою эрэйдэнэн ыл, сыралаһан кыай.

Состязание сущ. күрэхтэһии состязание с. 1. (соревнование в чём-л.) куоталаһыы;

2. спорт, күрэхтэһии; состязание в беге сүүрүүгэ күрэхтэһии.

Сражение сущ. кыргыһыы, сэриплэһии сражение с. кыргыһыы, сэриилэһии. 
Борьба сущ. (спорт) тустуу; охсуһyу; мөккүhүу

борьба с засолением и заболачиванием тууһурууну уонна бадараанныйыыны утары охсуһyу (нүөлсүтүллэр сиргэ ууну наһаa куттарыыттан сир бадараанныйыытын утары уонна ууну кытта киирэн сир ньуурун силистээх аранатыгар элбэх туһата суох туустар мунньуллубаттарын хааччыйар үлэлэри ыытыы уонна итинник дьаһаллары олоххо киллэрии.)

Война сущ. Сэрии война ж. сэрии, сэриилэһии; Великая Отечественная война АБа дойду Улуу сэриитэ; гражданская война гражданскай сэрии.

Столкновение с. 1. анньыһыы; столкновение судов суднолар анньыһыылара;

2. (конфликт) харсыһыы; столкновение противоположных интересов утарыта интэриэстэр харсыһыыла-ра;

3. (спор, ссора) хабырыйсыы.иирээн; между ними произошло столкновение кинилэр икки ардыларыгар иирээн буолбут;

4. (схватка, стычка) хабырыйсыы, хапсыһыы, ытыалаһыы; вооружённое столкновение сэбилэниилээх хапсыһыы.

Сопротивление с. 1. (Әействие) утарылаһыы, утарсыы;

2. физ. утарыы; сопротивление материалов физ., тех. Матырыйаал утарыыта

(1) матырыйаалларформаларынуларытыы-га бэриммэт свойстволара;

(2) матырыйааллар, массыыналар, mу ту улар оноһууларын бөБөтүн уонна олору уларытыы көрүннэрин ту стар ынан үөрэх).

\section{Единоборство с. күөн көрсүу (со5отохтуу охсуһуу).}

Деятельность ж. деятельность, үлэ, үлэлээһин; революционная деятельность революционнай үлэ; научная деятельность научнай деятельность.

Преодоление $c$. кыайыы, туорааһын, тулуйуу; преодоление трудностей ыарахаттары туорааһын.

Жизнь сущ. (ж. р.) олох жизнь ж. 1. олох, тыын, тыыннаах буолуу; жизнь человека киһи оло5о; борьба за жизнь тыыннаaх буолар иһин охсуhyу; отдать жизнь за родину төрөөбүт дойдун иһин тыыннын биэр; лишить себя жизни тыыннар тиин;

2. (продолжительность существования) олох, саас, тыыннаах сылдьыы; в течение всей жизни сааһын тухары; всю свою жизнь он отдал делу кини олоБун бүтүннүүтүн үлэ丂э биэрбитэ; на склоне жизни кырдьар caаhыгар; при жизни тыыннаабар; никогда в жизни сааспар биирдэ да;

3. (деятельность человека, общества) олох; обще- ственная жизнь общественна» олох; культурная жизнь культурнай олох;

4. (реальная действительность) олох, баар олох; случай из жизни баар олохтон түбэлтэ; провести в жизнь решение быһаарыыны олоххо киллэр;

5. (оживление, деятельность) тыас-уус, барыы-кэлии, сэргэхсийии; улицы полны жизни уулуссаларга барыыкэлии баһаам; жизнь в доме начинается рано тыас-уус дьиэьэ эрдэттэн сақаланар; жизнь так и кипит в нём кини сэргэхсийбитэ олус; \# не на жизнь, а на смерть өлөр тыыны харыстаабакка, өлөру-тиллэри кэрэйбэккэ; между жизнью и смертью өлөр-өлбөт ыккардынан; по гроб жизни тыыннаах тухары; подруга жизни олох до5оро. [СЯЯ Э.К. Пекарский, 1958: 2863].

В качестве яркой иллюстрации репрезентации концепта «борьба» в якутском эпосе можно привести олонхо Данилова В.Д. «Бүдүрүйэри билбэтэх борон турақас аттаах Батыйа Бэрт бухатыыр». В олонхо описывается дружба и борьба якутских и эвенкийских богатырей с силами зла [Данилов, 2010].

В якутской литературе концепт «борьба» представлен в известном романе Н.Е. Мординова «Весенняя пора». В произведении, которое называют якутской эпопеей, «отображены бесправное, угнетенное положение якутской бедноты до Великой Октябрьской социалистической революции, борьба трудящихся за Советскую власть, за право жить по-новому» [Мординов, 1978].

Кроме этого, в работах литературоведов, монографиях, посвященных исследованию творчества якутских писателей, мы можем встретить интересующий нас концепт: Окорокова В.Б. «Олох - үйэлээх хапсыһыы. народнай суруйааччы Е. П. Неймохов оло5о уонна айар үлэтэ» (2015), Алексеев Е.Е. «А.Е. Кулаковский и XXI век» (2002) и других. Во втором издании автор исследует место, роль и значение А.Е. Кулаковского в духовной культуре якутского народа. Во втором разделе, названном «Борьба за Кулаковского», автор на основе документов объективно показывает напряженность и страстность борьбы как противников Кулаковского, пытавшихся навсегда похоронить его, так и защитников, основавших его духовное наследие для народа. Изучая творчество поэта и ученого на протяжении многих лет, автор обнаружил много сведений и фактов о неизвестных ранее читателям произведениях поэта. В этой книге впервые публикуется пять произведений, бесспорно принадлежащих перу А.Е. Кулаковского [Алексеев, 2002].

Часто методом описания представляется концепт «борьба» в спортивной литературе. Это связано с тем, что «тустуу» в переводе на русский «вольная борьба», вид спорта. В данном виде спорта у нас есть наибольшее количество спортсменов, завоевавших олимпийские медали, что сделало данный вид в нашем регионе спортом 
номер один. В образовательном процессе университета, конечно, понятие «борьба» часто фигурирует в различных работах как преподавателей, так и студентов, начиная с методических разработок и заканчивая выпускными квалификационными работами.

Спортивнай тустуу былыргыттан баар спорт көрүнэ. Грецияқа Олимпиадақа күрэхтэһии биир көрүнүнэн көстөр. Оннооқор Платон, Пифагор көхтөөх кыттыыны ылбыттарын бүгүннү күннэ диэри суруйаллар. Оттон римляннарга ол тустуу ордук сайдан, бэйэлэрин истэригэр профессионал тустууктар баар буолбуттар. Ол туһунан 1980 сыллаахха тахсыбыт энциклопедическай тылдьыкка маннык диэбиттэр: «Борьба - один из самых древних и любимых народом видов спорта. Истоки ее зарождения уходят в глубины веков. Еще в первобытнообщинном строе человеку приходилось вступать в единоборства» [Энциклопедия, 1980: 172].

Таким образом, в якутской лингвокультуре концепт «борьба» отражает быт и обычаи, традиции простого народа:

1. Тустуу спорт, борьба; хапсабайдаһан тустуу борьба хапсагай (вид национальной борьбы); көнүл тустуу вольная борьба; классическай тустуу классическая борьба; тустуу ньымалара приёмы борьбы.

2. Революционный прил. революционнай; революционная борьба революционнай охсуhyy.

3. Кылаассабай классовый; кылаассабай охсуhyу классовая борьба.

4. Героический прил. героическай, геройдуу; героическая борьба геройдуу охсуһyу.

5. Идеологический прил. идеологическай, идеология; идеологическая борьба идеологическай oxcyhyy.

6. Непримиримый прил. эйэлэспэт, кырыктаах; непримиримая борьба эйэлэспэт охсуhyу.

7. Фракционный прил. фракционнай, фракция; фракционная борьба фракционнай охсуhyу.

8. Күлүгээннээһин хулиганство; күлүгээннээһини утары охсуhyу борьба с хулиганством.

9. Конкурентный прил. конкуренциялаһар (барыс былдьаһан куотуһар); конкурентная борьба конкуренциялаһар охсуhyу.

10. Неустанный прил. мөлтөөбөт, ахсаабат, салгыбат; неустанная борьба ахсаабат охсуhyу

Кочнев В.П. отмечал: “Вольная борьба в Республике Саха (Якутия) является в последнее время развитым видом спорта. В 1954 году Республиканский комитет физкультуры и спорта принял решение развить этот вид спорта. В начале пути в вольной борьбе были сложные условия, которые мешали ее развитию. Румянцев В. и Григроьев К. окончив в 1955 году педагогический институт имени А.И.Герцена, вернулись на родную землю, в родные края. Н.Н.Тарский, В.Румянцев, К.Григорьев, И.Малыхин и Г.Семенихин стали первопроходцами в становлении вольной борьбы в Республике Саха (Якутия)" [Кочнев 2006: 68].

Первый чемпионат по вольной борьбе в Республике Саха (Якутия) был проведен в 1956 году, где принимали участие 34 борца. В дальнейшее развитие вольной борьбы большой вклад и много труда внес заслуженный тренер СССР уроженец Чурапчинсого улуса Республики Саха (Якутия) Д.П.Коркин, тренер Олимпийских призеров Р. Дмитриева, П. Пинигина, А. Иванова, а также воспитавший более 150 мастеров спорта. Он одним из первых пропагандировал и заинтересовал всех этим видом спорта в Республике.

Постепенно начинает развиваться научное терминоведение. В 30-е годы 20 века имело место увлечение разными терминами, например, изучали термин «культурная революция». После некоторого перерыва в 70-х годах 20 века изучение терминов вновь возродилось. После того, как якутский язык принял государственный статус в 90-х годах, специалисты начали углубленное изучение терминосистем и занялись вопросами перевода с русского языка на якутский. Но термины физической культуры и спорта, в том числе по вольной борьбе и борьбе хапса5ай, до настоящего времени глубоко не разрабатывались.

Рассматривая термины спорта, репрезентирующие концепт «борьба», мы обратили внимание на параллели номинаций спорта в русском и якутском языках. Также вопросы перевода с одного языка на другой на сегодняшний день привлекают все большее внимание исследователей. Как сказала Т.И. Петрова: «Чтобы якутский народ не исчез как народ, перевод необходим, чтобы якутский язык процветал, развивался и жил, чтобы наша разговорная речь изменилась и улучшилась».

Представим для примера перевод русских спортивных терминов на якутский язык на материале газеты "Спорт Якутии". На якутском языке приведен как материал литературного языка, так и разговорной речи.

Номинации, которые входят в ядро концепта, включают в себя термины-названия самой борьбы как вида спорта и термины-названия основных спортивных приемов данного вида спорта. Данные номинации активны в использовании, характерны как для литературного языка, так и для разговорной речи.

Необходимо отметить, что параллельно в Республике Саха (Якутия) культивируются следующие виды борьбы:

Корякская национальная борьба РСФСР 1961 г. в Петропавловске-Камчатском крае м.с. ЯАССР В. Ефремов. 


\begin{tabular}{|c|c|c|c|}
\hline Русский термин & $\begin{array}{c}\text { Большой толковый словарь якутского } \\
\text { языка. Под ред. П.А Слепцова. }\end{array}$ & $\begin{array}{c}\text { Разговорная речь } \\
\text { этиллэринэн }\end{array}$ & Литературный язык \\
\hline Борец & тустуук, тустааччы & бөБес, тустуук, тустукист & Тустуук, бөБөс \\
\hline Борьба & тустуу, курэс & тустуу & Тустуу, күрэс, хапсыһыы \\
\hline Батай & & батаай & Батаай ньымата (3.Батаев) \\
\hline вольная борьба & - & көцул тустуу & Көцул тустуу \\
\hline Борцовки & - & борцовка & Борцовка \\
\hline букет Благидзе & - & Благидзе букета & $\begin{array}{c}\text { Благидзе букета, } \\
\text { благидзе } \\
\text { ньымата }\end{array}$ \\
\hline Вертушка & [кулахаччы] & вертушка & $\begin{array}{c}\text { Кулахачытыы, } \\
\text { кулахаччы }\end{array}$ \\
\hline Касание & дабайыы, та арыйыы & таарыйыы & Сири таарыйыы, дабайыы \\
\hline Кочерга & $\begin{array}{l}\text { [уөттурэх, } \\
\text { кулүүкэ] }\end{array}$ & кочерга & Кочерга, үөттүрэх \\
\hline Ключ & күлүүс & күлүүс & Күлүүс \\
\hline Лампочка & [лаампа] & лампочка & Лампочка \\
\hline Mapuo & - & марио & Марио ньымата \\
\hline Мельница & [миэлицсэ] & мизлицсэ & Миэлинсэ \\
\hline Mocm & [муоста] & мостик & Муостук \\
\hline Накат & $\begin{array}{c}\text { [үрүт сабыы; } \\
\text { төкүнүт, үнкүрүй] }\end{array}$ & накаат & Накаат \\
\hline Ножницы & [кыптыый] & ножницалааһын & Кыптыыйдааһын \\
\hline Нырок & [yмсаах] & ныроктааһын & $\begin{array}{c}\text { Ныроктааһын, умсан киирии, } \\
\text { умсаах }\end{array}$ \\
\hline Партер & - & партер & Партер \\
\hline Подножка & атахтааһын & атахтааһын & Атахтааһын \\
\hline Подсечка & төрдүнэн быһа охсуу, быһан ылыы] & атахха тэбии & Атахха тэбии, хатыйыы \\
\hline
\end{tabular}

Хомуур тустуу «групповая борьба» - данный вид борьбы описывается в учебном пособии д.п.н., профессора Н.К. Шамаева «Семейное физическое воспитание на основе национальных традиций». Это вид групповой борьбы хапсагай, где участвует большое количество детей и подростков. Участники делятся на равные по количеству и силе команды. В правилах разрешается нескольким атаковать одного участника, возможны и другие варианты. По договоренности разрешается сражение опытных сильных борцов против нескольких участников [Шамаев, 1996:56].

Хабыр хапса5ай - борьба, где разрешается наносить удары ногами и руками. Проигрывает спортсмен, упавший на три точки.

Делмачак «борьба» - у эвенков. Данная борьба напоминает современную вольную борьбу и хапса- гай одновременно. Борцы должны выбить соперника из равновесия и повалить на спину, на бок или на живот. Если во время поединка соперник упал на колени, это не считается поражением. Но если упал на колени три раза подряд, то ему засчитывается поражение. Соревнование проводится на ровной поляне летом и зимой во время различных праздников. В соревнованиях участвуют с 7 лет. Во время схватки разрешается использовать различные приемы, подсечки, толчки и т.Д., не разрешаются удушающие приемы, удары кулаками, локтями, коленями, головой и хватание за волосы.

Норсапкил «борьба на поясах» - у эвенков. Двое участников стоят лицом друг к другу и захватывают сзади за пояс соперника. Борьбу начинают по сигналу, стараясь уронить соперника на землю. Тот, кто коснется земли любой частью тела, тот проигрывает. 
Национальная борьба на кушаках (поясах)- эвенков. Данный вид борьбы эвенков проводится на открытом воздухе в снежное время года. Борцы, обнаженные по пояс, выходят в круг, образованный зрителями. Во время борьбы запрещается отрывать руки от кушака (пояса). Если кто-то во время борьбы уберет руки, тот считается проигравшим. Правила как в борьбе хапсагай: вынудить соперника коснуться земли любой частью тела. По времени борьба не ограничивается. С 1988 года, с утверждением правил по национальным видам спорта, установ- лены весовые категория до 65 кг и выше, время схватки - 6 мин. [Максимова 2007: 76].

Таким образом, необходимо отметить широкое употребление терминов спортивной борьбы в настоящее время в республике, что связано, с одной стороны, активизацией населения в плане занятий спортом, с другой стороны, целенаправленной деятельностью специалистов по разработке научной терминологии физической культуры и спорта.

\section{ЛИТЕРАТУРА}

1. Алексеев Е.Е., А.Е. Кулаковский и XXI век. — 2002

2. Данилов В.Д., Бүдүрүйэри билбэтэх борон тураБас аттаах Батыйа Бэрт бухатыыр. олонхо. - 2010.

3. Кочнев В.П. По ступенькам к вершине Олимпа. - Якутск: 2006. - 231 С.

4. Максимова, 0.А. Эвенкийские игры и состязания для учащихся национальной школы коренных народов Республики Саха (Якутия): учебное пособие / 0.А. Максимова. - Якутск: Изд-во ЯГУ, 2007. - 76 с.

5. Мординов Н.Е., Весенняя пора. роман. - 1978

6. Пекарский Э.К., Словарь якутского языка. [в 3-х томах]. — 1958

7. Русско-якутский словарь. - 1968. - 720 С.

8. Степанов Ю.С. Константы: Словарь русской культуры: Опыт исследолвания. -М., 1997. - 825 С.

9. Шамаев Н.К., Семейное физическое воспитание на основе национальных традиций: учебное пособие. 2-е изд., доп. и изм. / Н.К. Шамаев. - Якутск: Издво Якутский ун-та, 2009. - 96 с.

10. Энциклопедия словарь юного спортсмена. - Москва. «Педагогика».: 1980. - 480 С.

( К Кудрин Егор Петрович (kudrinep@mail.ru), Павлова Ирина Петровна (ipavlova27@mail.ru).

Журнал «Современная наука: актуальные проблемы теории и практики»

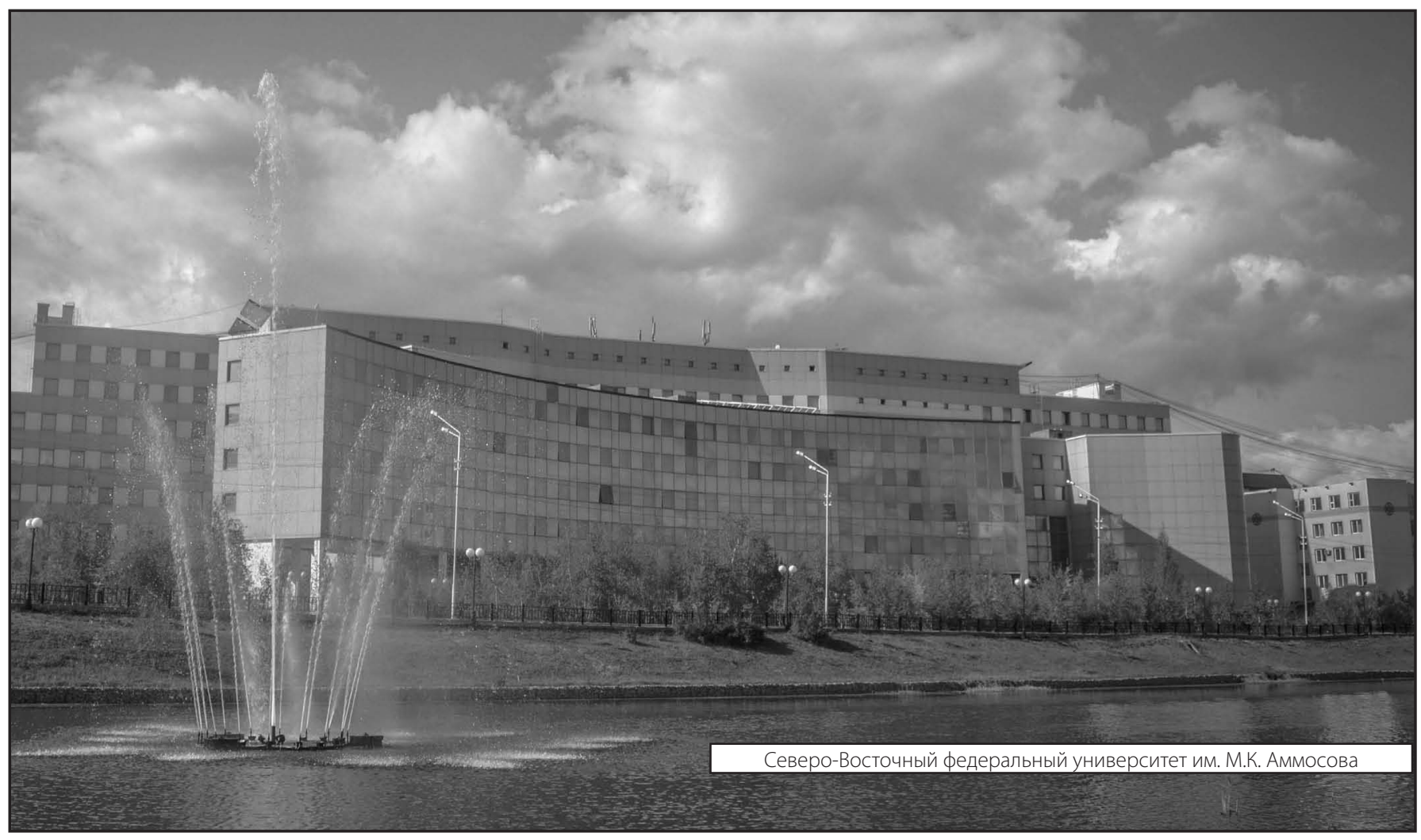

